\title{
Téoros
}

Revue de recherche en tourisme

\section{Art for tourists}

Capitalist integration or cultural resistance

\section{Jeffrey O’Mailley}

Volume 6, numéro 3, décembre 1987

Le tourisme, phénomène mondial

URI : https://id.erudit.org/iderudit/1080603ar

DOI : https://doi.org/10.7202/1080603ar

Aller au sommaire du numéro

\section{Éditeur(s)}

Université du Québec à Montréal

\section{ISSN}

0712-8657 (imprimé)

1923-2705 (numérique)

Découvrir la revue

\section{Citer cet article}

O'Mailley, J. (1987). Art for tourists: Capitalist integration or cultural resistance. Téoros, 6(3), 22-26. https://doi.org/10.7202/1080603ar d'utilisation que vous pouvez consulter en ligne.

https://apropos.erudit.org/fr/usagers/politique-dutilisation/ 
Capitalist integration
or cultural resistance
Art

for

tourists
In contrast to most economic and geographic perspectives on tourism, much of the recent anthropological work includes a growing body of ethnographic research focussing on precise examples of cultural change in response to the expansion of a tourist frontier. While it is difficult sometimes to differentiate the impact of the tourist industry on a culture from the phenomenon of societal change in response to the generalized expansion of market relations and occidental culture, the production of art seems particularly responsive to tourist penetration. This paper will review some of the relevant ethnographic literature in order to ascertain whether the recent changes in artistic production in Third and Fourth World social formations in response to tourism indicate in all cases an integration and subsumption into capitalism, as traditional dependency theorists would predict, or whether some of the changes might be more properly described as mechanisms of resistance to the challenging capitalist order. We thus hope to analytically "break down" the concept of cultural distortion into the more specific concepts of "cultural disintegration" and "cultural resistance".

\section{Theorizing the Cultural Impact of Tourism}

The trickle down theory of cultural change in response to tourism, represented by such authors as Matthews (1978) and Lowenthal (1972), emphasizes the close relations which develop between local comprador bourgeoisies and foreign tourists/tourist industry developers. The extreme dependency of the local bourgeoisie on metropolitan economy and culture combine with their dominant and determining role in the national context, making the class an ideal conduit for occidental cultural values to be diffused to the masses. This model, depending as it does on an elite class completely shaped by external influences co-existing with a population which aspires to rather than resists the elite's example, is far too mechanistic to be of much use in explaining the variety of cultural change which does occur.

\begin{abstract}
"Mass seduction/demonstration theories" are an adaptation of the trickle down model without the intermediate step of the conversion of the local bourgeoisie. The opulent and hedonistic lifestyle of tourists is described as overwhelmingly tempting to the impoverished residents who thereafter dump their entire cultural conditioning and embrace Levis and wienerschnitzel. The result is some kind of cultural limbo, never really entering the metropolitan culture but no longer having an indigenous one. As mechanistic and unconvincing as the trickle down theories, this perspective has the added disadvantage of having no explanation for cultural distortion but envy and stupidity.
\end{abstract}

The "commodification theory" is the preferred explanation of those dependency theorists with a neo-Marixst inclination. $\mathrm{Pe}$ rez, in one of the seminal critiques of tourism in the West Indies, seems to combine Fanon with Marx:

\footnotetext{
"The task of breaking existentially with the colonial past - on West Indian terms - re. mains unfulfilled as long as metropolitan authorities continue to define Caribbean history as a tourist attraction. The very culture passes into dependency on tourist patronage. $A n t$, music, dance and literature become the patrimony of an expanding tourist economy... In this sense, culture does not function in its historical role as an agent of national unity precisely because of its inability to assume and maintain viable national proportions", (1)
}

Later writers have added additional insight to this perspective by analysing the social discourse around the creation of tourist sites ${ }^{(2)}$ and the commodification of ethnicity. To the extent that the incorporation of culture into the international capitalist economy is seen to determine the culture thereafter, this model is as mechanistic as the trickle down theory. But inasmuch as the commodification of culture is seen as an influence on cultural development rather than a determinant. this is a theoretically useful and easily substantiable hypothesis.

While those academics who have focussed more specifically on how art changes in response to tourism often have unclear or eclectic theoretical influences, their identification of the complex range of possible changes provides insight by pointing to the need for a non-deterministic, non-linear explanatory framework. Graburn initially differentiates the arts of the Third World according to destination audience - "inwardly directed arts "and" those arts made for an external, dominant world ${ }^{\prime}(3)$. He also acknowledges the distinctions made earlier by Maquet:

$\because$... aesthetic productions may be (I) art by destination, that is to say, they may have been intended by their producers to be art per se or to have a primarily aesthetic locus, or (2) they may be art by metamorphosis, in which case they were deemed an sometime after they were originally made... $\left.{ }^{+\lceil 4}\right)$

Graburn's early work combined the distinction on the basis of audience with a distinction on the basis of the aesthetic roots of the art, coming up with the schema illustrated in Table 1 .

Graburn identifies a number of preconditions necessary for the emergence of each category and uses examples from different social formations to differentiate a variety of evolutionary tendencies:

\footnotetext{
"Beyond the raw forces of "unit cost" are more subtle matters of content and taste, which force peoples to produce for sale things that are acceptable to a public that already has its preconceptions of what is typical and appropriate. For instance, the travelling public of the Western world seems to believe that souvenirs should match the skin color of their producers, particularly that black people should produce black an objects... +45)
} 
In general, the arts intended for consumption by outsiders are subject to a great number of contingencies, needing to bridge the aesthetic senses of producer and consumer, projecting a suitable ethnic or exotic image, being easily transportable, not fragile, easily identifiable as art, and dustable. These contingencies often result in tendencies towards miniaturism, naturalism or grotesqueness.

The art form that might be predicted by our commodification theory would be the souvenir, where profit is more important than communication. The "ewho-kitsch" of the souvenir is so reduced in symbolic content, so conforming "to the consumers" popular notions of the salient characteristics of the minoriry group ${ }^{\text {"(f) }}$, that it is perhaps inappropriate to even call it culture; Perez's assertion is confirmed. But Graburn also describes the existence of "commercial fine arts" , made with sale in mind but with "culturally embedded aesthetic and formal standards "(7), and "assimilated fine arts".

"characteristic of extreme cultural domination and hence a desire to assimilate' '(8). Graburn went on in later work to stress that his schema is only an approximation and that evolution is not unilinear, "... but a number of situationally created processes which form an interconnected network in the nexus of tourism, art, and ethnicily ${ }^{\mathrm{w}} \boldsymbol{y}$. His great contribution to the theoretical debate was his confirmation of the validity of several theories in specific conjunctures, thus disproving any of their claims to universality.

Given both the diversity of artistic change in response to tourism and art's communicative function, more and more scholars seem to be drawing on linguistic theory for explanatory insights. An early example of this is found in Ben Amos:

"Tourist art... operates as a minimal system which must make meanings as accessible as possible across visual boundary lines... (a) reduction in semantic level of traditional forms, expansion of non-tradivional secular motifs, and utilization of adjunct communicative systems (thus occurs)". (10\%

Ben Amos continued her use of linguistic theory by comparing tourist art's evolution to that of pidgin languages (langages "petitnègre"). Both communicative systems are forms of cross-cultural communication dependent upon "lowest common denominafor" symbols, both standardize quickly, emerge from strictly commercial contexts, and in the end are incomplete symbolically for both communicating groups. While art in general is a restricted system paralleling Bloch's "ritual language" (11), tourist art is even more restrictive, not even producing satisfaction for the artist. We could say that the removal of meaning from the local context and the erosion of traditional patronclient relations intensifies artistic alienation in a manner paralleling the symbolically incomplete experience of speaking pidgin languages.

TABLE 1:

Graburn's Art Categorization System

Aesthetic-Formal Sources and Traditions

Intended

Audience

\begin{tabular}{|c|c|c|c|}
\hline 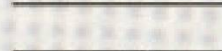 & Minority Society & Novel/Synthetic & Dominant Society \\
\hline $\begin{array}{l}\text { Minority } \\
\text { Fourth } \\
\text { World }\end{array}$ & $\begin{array}{l}\text { Functional } \\
\text { Traditional } \\
\text { e.g., Lega, Maori } \\
\text { marae, some } \\
\text { pucblo pottery }\end{array}$ & $\begin{array}{l}\text { Reintegrated } \\
\text { e.g., Cuna*molas, } \\
\text { Pueblo kachinas }\end{array}$ & $\begin{array}{l}\text { Popular } \\
\text { e.g., Zaire, } \\
\text { Mozambique, } \\
\text { Navajo jewelery }\end{array}$ \\
\hline $\begin{array}{l}\text { External } \\
\text { Civilizations }\end{array}$ & $\begin{array}{l}\text { Commercial } \\
\text { Fine arts } \\
\text { e.g., Maori } \\
\text { woodcarving, New } \\
\text { Guinea shields }\end{array}$ & $\begin{array}{l}\text { Souvenir } \\
\text { Novelty } \\
\text { e.g., Seri, } \\
\text { Makonde carving: } \\
\text { Xalitla amate }\end{array}$ & $\begin{array}{l}\text { Assimilated } \\
\text { Fine arts } \\
\text { e.g., Santa Fe } \\
\text { Indian painting, } \\
\text { Namatjira water- } \\
\text { colors, Eskimo } \\
\text { prints }\end{array}$ \\
\hline
\end{tabular}

Source: Graburn (1976: p. 8)

Graburn, discussing Ben Amos, stresses that "pidgin" art is a useful categorization for those tourist arts which emerge from societies lacking the necessary cultural strength, independence from overwhelming external influenoes, and internal socio-economic conditions to resist in a more effective manner ${ }^{12 y}$. In such cases, artistic evolution involves " $"$, material and cognitive simplification commensurate with the more restricted codes and the selection of simple univocal symbols out of the original multivocal characteristics of the embedded functional arts' (13). More effective cultural resistance to Western hegemony, however, can create "creole" art, a new art form that manages to be symbolically complete while avoiding "museumification" in the ethno-kitsch of souvenirs. These forms link social formations to the external world while being '. identified with specific self-conscious ethric and national groups... (and serving) as powerful markers of identity (14).

Graburn's identification of the diversity of artistic evolution and its linkage to not only the tastes of the consumers but the cultural and economic structures of the producers gives us a basis from which we can begin to analyse specific examples of the impact of tourism on art. Art is a communicative system and, like language, must be analysed not only in terms of the sign itself but in terms of the social relations within which the sign is produced, transmitted, received and interpreted. Thus the tourist industry will not only change what is produced artistically and the relations of production and exchange: the pre-tourist industry relations of cultural/economic production will also affect the manner in which the tourist market relations penetrate.

\section{Commodification and Competition}

The commodification of artistic creations in societies which had previously produced and exchanged art "freely" for purposes of kinship maintenance, spiritual edification, or caste duty has dramatic impact in both economic and cultural terms. In most cases we reviewed, tourist industry penetration resulted in enhanced income for producers who would market their own creations, though in some instances "simple commodity producrion " had been totally eradicated by industrial "art" production with producers being exploited through a wage labour system. In addition to changes in form as noted by Graburn, class and gender relations can be transformed while the symbolic content of the product is often greatly reduced.

The case of the Kulebele of the Ivory Coast, documented by Richter ${ }^{(15)}$, illustrates many of these phenomena. Traditionally the Kulebele combined subsistence farming with the carving of art objects and implements for other groups in the northern Ivory Coast. Their carving was exchanged by migration to a host village which would provide land and some surplus produce in exchange for carvings over the period of residence. Supernatural sanctions were imposed on nonKulebele who witnessed carving techniques and income in poor times was supplemented by the Kulebele's ability to transform into hyenas in order to steal cattle. The successful entry of the Kulebele into the tourist art market has produced dramatic changes.

"Social change that has occurred because of tourist art market participation is apparent in basic institutions, such as migration 
patterns and relations with non-Kulebele host-villagers; supernatural sanctions; male/female economic spheres and relationships; kinship and inheritance of wealth; residence patterns; economic opportunism; political authority; and secret society (poro) inter-relationships ${ }^{* \prime}$,(16)

The traditional symbiotic relationship between the Kulebele and their hosts has broken down as the income from the tourist market discourages the production of goods for the host villages and makes subsistence farming unnecessary. As more Kulebele migrate to the regional urban centre to market more directly to tourists, the traditional gender division of labour between male carvers and female farmers breaks down due to lack of farmland, causing gender tension and robbing women of their economic power. Richter also explains that supernatural sanctions are no longer imposed, nor does thievery continue: "There is no longer any need to protect their exclusivity over the carving market because the demands of the tourist an market are so great that it absorbs everything the Kulebele carve" "(17). Enhanced income is also transforming the class relations of the region. The Kulebele have ventured out of family production units and now even hire non-Kulebele wage labour to assist in artistic production. Extra income is often invested in land and houses for the rental market, and

"Landlordism has become an ideal to which all Kulebele aspire "(18)"

In Tonga, a growing tourist market for tapa, a parchment traditionally manufactured and decorated by women, has similarly had both economic and cultural implications. Johnson explains that before the advent of the tourist market, tapa and similar products " "... were primarily utilized for practical and ceremonial purposes and were not considered" ant "as such", but, "... as a result of the rapid development of the visitor industry, cultural items have now taken on a new value - both in the eyes of the Tongans and of the tourists (19). Physical changes in tapa production include a move towards smaller pieces and a condensation and a consolidation of patterns, but the more significant change lies in the pattern of exchange amongst Tongans. By 1982, Thaman had noted that a large piece of tapa cloth had increased in price form $\$ 30-\$ 50$ a few years before to as much as $\$ 300$, and he predicted that "... increasing tourist demand for some of these products... may make some items disappear from use in Pacific island ceremonies and in maintenance of kinship and social ties" ${ }^{* 20)}$. Unlike the case of the Kulebele, however, increased income is spread fairly evenly over households, preventing the emergence of tourist artfinanced landlords or bosses. In general, $\mathrm{Pa}$ cific island handicraft and art sale has been interpreted as having positive income distribution effects because most products are sold directly by the producer to the tourist, the products are produced by most households, and positive backward linkages have occured to the cultivators of agricultural inputs such as paper mulberry. Where income effects are being felt is within the household, where women's traditional control of tapa production has resulted in a situation where "... an industrious woman can make considerably more money than her husband, contributing up to $70 \%$ of the family's income ${ }^{\text {riz21). }}$

Examples of commodification leading to cultural denigration abound. In the Pacific island community of Rukua, the traditional spiritual ceremony of vilavilairevo (firewalking) was transformed into a major tourist attraction. Although income from performing the ceremony initially added significantly to the cash income of the communally organized Rukuans, the elaborate rituals behind the actual walking on coals have now all but disappeared. To make matters worse, villages now compete heavily to obtain contracts with hotels, and tourist interest in the event is appears to be declining just as villages become increasingly dependent upon it as a source of income $e^{(22)}$. In Thailand, Bali and Nepal, tourist industry officials have all had to deal with wide-spread public resentment of the industry's use of sacred objects, sites and rituals as tourist attractions. The Nepalese government has instigated workshop training to encourage the production of other high-quality art works in order to discourage theft, while the Thai and Indonesian governments are attempting to "sensitize" tourists through education campaigns $^{(23)}$.

A more extreme example of the possible social impact of "cultural commodification" " can be found in the Kamba wood carvers of Kenya. Geshekter outlines how production has shifted "... from an occupation formerly oriented towards domestic consumption into a "tourist art" industry" 124). Carvers interviewed by Geshekter openly admitted that their work can be shoddy and has little connection to any traditional belief system. Increased demand has "... pressured the canvers to expand and standardize production methods, simplify the designs, and all but eliminate any symbolic content (25). From depending primarily on a self-sufficient agricultural system, the Kamba now depend almost wholly upon piecework industrial art production. Unlike the cases reviewed above, however, the capitalist organization of this production minimizes the retention of earnings:

"I can safely estimate that the labour and
material costs for one ten inch antelope are
between fifteen and nineteen cents. Middle-
men retailers usually pay twenty-eight to
thirty-two cents per piece, selling them... to
local tourist for ninety cents, or whatever the
market will bear!' 20 ; The above examples suffice to conclude that Perez's concept of the commodification of culture is a useful theoretical framework. Despite the clearly capitalist structure of the international tourist industry, however, we see that cultural commodification is organized in different manners according to the social formation in question. Although some form of cultural degradation seems to be a frequent product of this process, economic effects vary considerably and cannot be easily predicted.

\section{The Creation of the Myth of the Individual Producer}

In contrast to the deskilling of artists into factory workers that was identified in the above example of the Kamba carvers, many traditional societies entering the tourist art market adopt the particularly Western notion of art as a product of creative individual genius rather than the society in which it is produced. This reconceptualization often has its roots in market transactions, as Western tourists often demand signatures on products labelled "art". Graburn gives the examples of Eskimo soapstone sculpture, Seri woodcarving, and Pueblo pottery, all art forms that have had signing introduced in response to Western demand.

In one Mexican example, fake names were signed on products by retailers to lend them the air of art. Despite previous traditions of identifying art as a social product or identifying an artist through familiarity with the product, or through the artist's caste or kin role, this Western notion of creative genius can diffuse into the producing population:

"This way of thinking has in turn been introduced into the cultures of the small-scale dominated peoples, with a resultant enhancement of individualism, competitiveness, and the emulation of the successful for his success rather than for the beauty or utility of his product... This cult of individualism, as opposed to cooperative egalitarian effort, fits a belief system that differentiates art from life and leaders from ordinary people".(27)

This phenomenon seems to be most prevalent when the art form in question resembles a pre-existing Western art form such as sculpture or painting and when artists have readily identifiable stylistic tendencies. It is much less likely to occur when the art form is unfamiliar, as is the case with totem poles and basket weaving. One intriguing byproduct of this process is the empowerment of artists that occurs through this Western notion of artistic genius; even when tourists despise or deride the social milieu from which Third World artists emerge, they often maintain a strong respect for the "artist". Artistic producers are thus placed in a key position of respect between social formations which enables them to play an especially important role in facilitating cultural resistance.

\section{Defining Identity Through Marketed Art}

The inverse of cultural deterioration as a result of tourist art market participation would be cultural defense or renewal. Under external economic and cultural threat, $a$ social formation may revive (or invent) ancient traditions and place new stress on " $e t h$ nic markers " such as dress, art, and language 


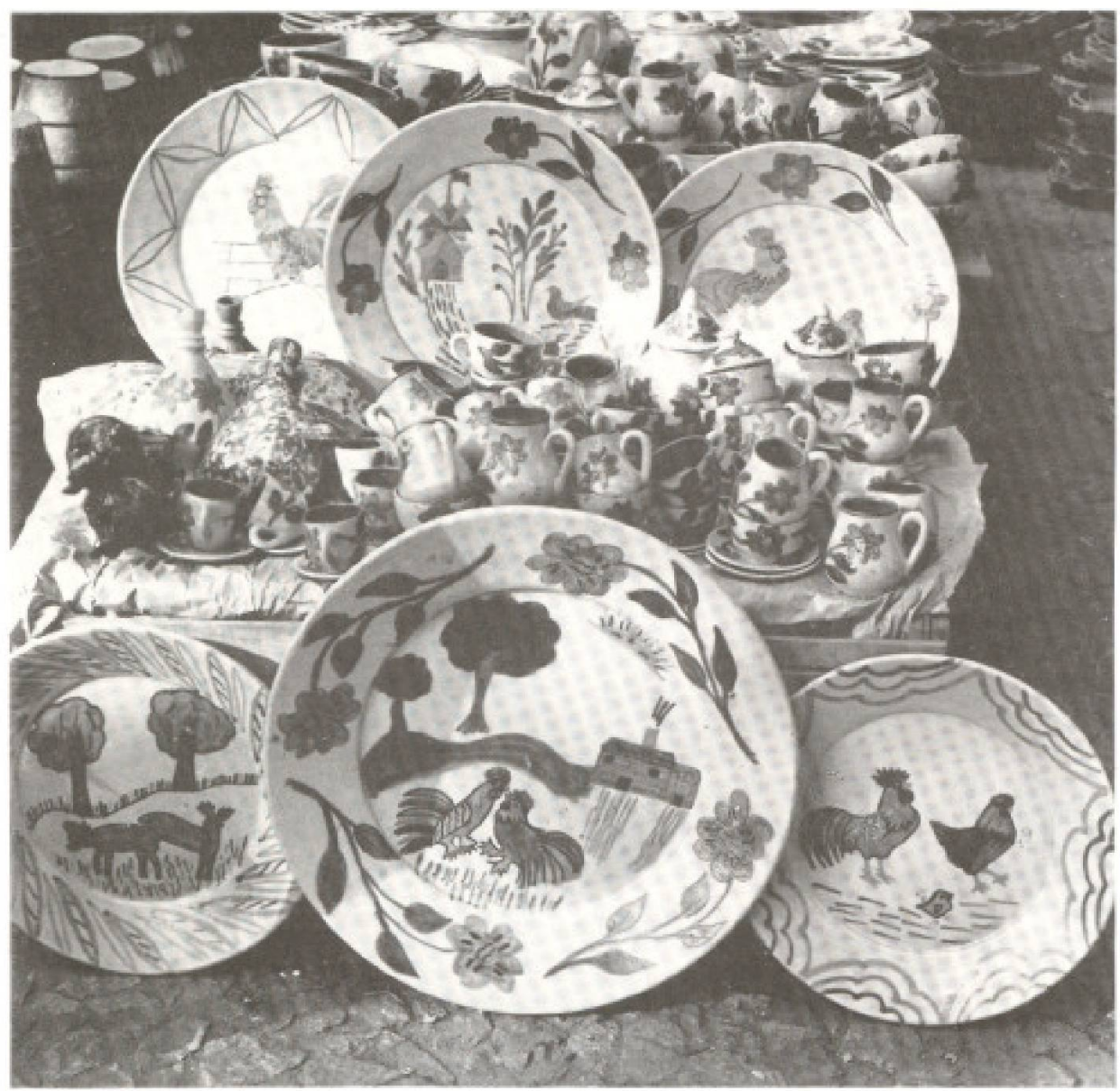

Planicies - vaisselle de redondo

in order to facilitate internal image maintenance and resistance to the external force. It is difficult, however, to decide when marketed art is being used as an identity defense mechanism and when the process of defining oneself both in opposition to and in accommodation to the outside merely narrows and restricts identity:

"In... the revivals of exotic "Aztec" themes in Ocumicho potiery and in the latest Xalitla bark paintings, it is hard to say whether the ethnic marker is totally imposed by promoters or whether it shows the influence of long-held beliefs in new syncretistic forms" "(28)

One can even question whether internally developed "ethricity" is in fact resistance or merely a more elaborate form of cooptation into global capitalist culture and economy. Regardless, to the extent that ethnic identity is not imposed and frozen, it is probably preferable to assimilation and subsumption under external forces.

A convincing example of the potentially positive impact of art market participation is found in Aspelin's study of the Mamainde of Mato Grosso, Brazil ${ }^{(29)}$. The Mamainde are in the enviable position of marketing their art through an "indirect tourist front". Travel to the area of the Amazon where they live is restricted by the national government, but their art is purchased by government agents who market it to tourists in special shops in tourist centres. Aspelin argues:
"... indirect contact through "indirect tourism" may, ceteris paribus, facilitate the preservation of cularal pluralism and cultural autonomy which direct tourism, involving the direct contact of tourists and their hosts, is more likely to alter, reduce or destroy" ". (30)

Given the desire of the Mamainde for a cash income to access to certain manufactured goods, the tourist art industry is clearly preferable to other possible interactive mechanisms such as commercial agriculture, dependence on government income support, or wage labour in local mines.

"... they chose the indirect tourist front, for it allowed them to maximize those things they held dear: their family and village life, their traditional work styles, and their traditional values (in shon their traditional culture)..

The focus of the inter-ethnic friction inherent in the contact situation was thus shifted from between the Mamainde and the local Brazilians to between the local Brazilians and their national institutions, for the local Brazilians did not much appreciate this opportunity for the Mamainde to obtain their trade goods in ways other than those which would provide them with Mamainde labor and Mamainde land"., (3)

Although this seems like a good example of defending culture through tourist art market participation, the advantages to the Ma- mainde are significantly reduced by their situation of extreme dependency. They neither created the marketing contact nor control the dual conditions of tourist interest in their product and government support through travel restrictions and art marketing.

MacCannell argues that one of the determinants of the impact of the tourist industry on ethnic identity is the choice of signs to be marketed:

when historical shrines are the atraction... they can be enjoyed by locals and tourists alike and augment the resources of the community's education system in a meaning ful way. But, if as a local representative of an allegedly colorful minority, you are the atraction, it is hard to figure out how you might come to benefit from the role or learn anything "ethnic" from yourself". (32)

MacCannell points out that we must avoid confusing resistance and renewal with the reification of "village life" into "... an interesting detail in the recreational experiences of a tourist from out of town " 735 , When art becomes merely part of the ethnic package, not only does the natural evolutionary dynamic get frozen, changes in style and form are no longer just questions of art, they are questions of ethnic marketability. In this case, MacCannell asserts, "it is not just ethnicity any more, but it is understood as rhetoric, as symbolic expression with a purpose or use-value in a larger system. This is the basis for a distinctive form of modern alienation, a kind of loss of soul... "(34)

\section{Cultural Production and Claims to Power}

The growing importance of the tourist art industry and its success at generating foreign currency has set up a contradictary dynamic in many Third World social formations. On the one hand, more and more intrusions are being made by states into mass or minority culture. The Thai government determines the legitimacy of art forms through this not-sosubtle message on all government issue tourist pamphlets: "To make shopping in Bangkok more pleasant and covenient for you, the Tourism Authority of Thailand has drawn up a list of reliable souvenir shops which have passed the screening of a committee on Souvenir Shop Standards Promotion...". The Indian government is even more straight-forward, instructing tourists in their "Travel Tips" pamphlet to never buy art or handicrafts from street vendors. The Tongan state takes a different approach, as noted by Johnson: "In a weekly broadcast on Radio Tonga, the Tongan Visitors Bureau encourages those who make handicrafts to do their best and to make what tourists like ${ }^{\prime(35)}$. Other common mechanisms used by the state in redefining authenistic culture include direct instructions to perform certain rituals at certain times and the more subtle technique of licensing "qualified" performers and artists. On the other hand, the legitimacy derived from market success oc- 
casionally facilitates the opposite process minority or mass claims on the state.

Comparing the respective fates of the Dayak's longhouse communities in Indonesia and East Malaysia is illustrative. In Indonesia, there has been little public or private sector interest in cultivating the tourist potentiality of these communities. The Indonesian government has thus gone ahead with its agressive policy of "civilizing " the Dayaks by relocating Javanese in their midst and through Islamization of education and law. The Malaysian state, in contrast, not only encourages tourism to the longhouse communities, they have appropriated their artistic productions in the marketing of Malaysia to foreigners. The Malaysian Dayaks have used this legitimacy to make claims on the state for financial support and administrative autonomy.

The role of Bali as Indonesia's principal tourist destination has given the Indonesian Hindus more power to resist the central government than the ill-fated Dayaks:

.... (an) official argued for the codification and enforcement of Balinese religion, as well as for a division of authority at the village level between administrative and religious leaders, partly in terms of the importance of preserving village rituals for tourism. Clearly tourism does not provide the original motivation here, but it is a convenient tool for attempting to enlist government support... The tourist importance of Balinese culture has enabled the Balinese to resist Indonesianization of their educational institutions and generally to receive a less haughty hearing in Jakarta..." $(36)$

The hill tribes of Thailand, fated to be living in a country obsessed with Thai heritage, the Monarchy, and Buddhism, have also noticed a recent change in policy. Indeed, instead of assimilation, the tourist authority now uses Karen dolls in their international advertising and argues for the preservation of the attractive "racial characteristics" of the hill tribes in their tourism plans.

\section{Conclusions}

The participation of previously isolated communities in the tourist art market is unquestionably a paradoxical agent of change. While we may easily dismiss the naive modernization assumption that tourist art market participation fosters cultural progress and economic development in some kind of automatic way, our examples point to the inadequacy of a "dependency" perspective which argues that tourism is simply an agent of the homogenizing and exploitative capitalist system. Not only is it impossible to generalize the impact tourist penetration will have upon art and the accompanying relations of production, it is also impossible to generalize the cultural and economic structuring of tourist penetration itself.

In certain isolated examples such as the firewalkers of Rukua and the tapa producers of
Tonga, existing internal relations of production - be they domestic or communal - were maintained, yet distinct economic and cultural changes occurred through the connection to the tourist market. In other cases notably the Kamba carvers of Kenya and the Kulebele of the Ivory Coast - more classic capitalist relations of production emerged along with the predictable income effects and cultural degradation. Yet if we accept Aspelin's assumption of a given desire for cash income to access trading goods, it would certainly appear that some communities or ethnic groups are better off risking the ill-effects of tourist art market participation than those of other "contact fronts".

In addition to the strengths of Perez's "commodification of culture" hypothesis already discussed, it would appear that another useful insight from dependency theory is the importance of economic and cultural self-determination as an evaluative criteria when analysing any particular contact between social formations. Especially in the difficult area of differentiating cultural renewal from ethnicity controlled and packaged for touristic consumption, the ability of a social formation to make its own cultural and economic choices is the closest thing to a guiding principle for development that we can identify.

\section{References:}

ASPELIN, Paul $(1977)$, The Anthropological Analyses of Towism... Annals of Tourism Research, 4 (pp. 135-160).

ASPELIN, Paul (1978), Indirect Tourism and Political Econowy. In Tourism and Cultural Change, Studies in Third World Societies $\# 6$.

BEN AMOS, Paula $(1977)$. Pidgin Languages and Tourist Arts. Studies in the Anthropology of Visual Communication, 4 (pp. 128-139).

BLOCH, Maurice (1974), Swmbols, Song. Dance and Features of Articulation. Archives Europeennes de Sociologie, 15 (pp. 55-81).

BRITTON, Stephen G (1982), The Powtical Econamy of Tourism in the Third World. Annals of Tourism Research, 9 (pp, 331-358).

ERISMAN, H.M. (1983), Tounism and Cutural Dependency in the West indies. Annals of Tourism Research, 10 (pp, 337-361).

GESHEKTER, C.L. (1978), International Towism and African Underdevelopment. In Tourism and Eeonomic Change, Studies in Third World Socleties $\$ 5$.

GRABURN, Nełson (1976), Introduction. In Ethnic and Tourist Arts: Cultural Expressions from the Fourth World, N. Grabum, ed., Berkeley: University of California Press.

GRABURN, Nelson (1984), The Evolution of Tourist Arts. Annals of Tourism Research, 11 (pp. 393-419).

JOHNSON, R.B. (1978). The Role of Tounism in Tongan Culture, In Tourism and Cultural Change, Studies in Third World Societies

LANFANT, Marie-Francoise (1980), Tourism in the Process of intemstionshization. International Social Science Journal, 32 (pp. 14-43).

LOWENTHAL, David (1972), West Indian Societies;, New York: Oxford University Press.

MACCANNELL, Dean [1976). The Tourist: A New Theory of the Leisure Class, Naw York: Schocken.

MACCANNELL, Dean (1984), Reconstructed Ethnicity: Tourism and Cultural fdentity in Third World Communities. Annals of Tourism Research. 11 (pp. 375. 3911
MAQUET, J. (1971), Introduction to Aesthetic Anthropology. Reading. MA: Addison-Wesiey.

MATTHEWS, H.G. (1978), International Tourism: A Political and Social Analysis, Cambridge: Schenkman Publishing $\mathrm{Co.}$

OKOTAI, T., HENDERSON, P., FOGELBERG, I. (1982), The Cultural lmpact of Tourism. Art Forms - Revival or Degradation?. in Rajotte (1982), op. cit. infra.

PEREZ, L. (1975), Underdevelopment and Dependency: Tourism in the West Indies, University of El Paso: Conter for Inter-American Studies.

RAJOTTE, Freda (ed.) (1982). The Impact of Tourism Development in the Pacific. Trent University, Canada: Environmental \& Resource Studies.

RAJOTTE, F, and TUBANAVAU, M. (1962), The knpget of Tourism upon Vilavilairevo, In Rajotte (1982), op. cit.

FICHTER, Delores (1978), The Tourist Art Market as a Factor in Social Change. Annals of Tourism Research, 6 (pp, 323 398).

TURNER, L and ASH, J. (1976), The Golden Hordes: International Tourism and the Pleasure Periphery, New York: St. Martin's Press.

UNITED NATIONS (1963), Recommendations on International Travel and Tourism, Rome: U.N. Conference. WOOD, Robert (1984), Ethnic Tourism, the State, and Cuitural Change in Southeast Asia. Annals of Tourism Research, 11 (pp. 353-374).
Notes:
(1) Perez (19/5; 25-26)
(2) MacCannell (1976).
(3) Graburn (1976).
(4) Maquet (1971).
(5) Graburn (1976: 16)
(6) Graburn (1976: 6).
(7) Ibid.
(8) Ibid.
(9) Graburn (1984: 395).
(10) Ben Amos (1977: 9).
(11) Bloch (1974).
(12) Graburn (1984).
(13) Graburn (1984: 414-415).
(14) Graburn (1984: 407).
(15) Richter (1978).
(16) Richter (1978: 325).
(17) lodem (328).
(18) Richter (1984: 334).
(19) Johnson (1978: 57 )
(20) Thaman (personal notes).
(21) Johnson (1978: 64).
(22) Rajotte and Tubanavau (1908; 127 )
(23) Britton (1978: 257 ).
(24) Geshekter (1978: 74).
(25) Ibid.
(26) Idem (76).
(27) Graburn (1976: 22-23).
(28) Idem (27).
(29) Aspelin (1978).
(30) Idem (1-2).
(31) Idem (13).
(32) MacCannell I1994- 396!
(33) Idem (387)
(34) Idem (385)
(35) Johnson (1978; 60).
(36) Wood (1984) 